\title{
Nematicidal Activity of Essential Oils and Their Components Against the Root-Knot Nematode
}

\author{
Yuji Oka, Sengul Nacar, Eli Putievsky, Uzi Ravid, Zohara Yaniv, and Yitzhak Spiegel
}

First and sixth authors: Department of Nematology, Agricultural Research Organization (ARO), The Volcani Center, Bet Dagan 50250, Israel; second author: Biology Department, Faculty of Science, Kahramanmaras Sutcu Imam University, K. Maras, Turkey; third and fourth authors: Department of Aromatic, Medicinal, and Spice Crops, ARO, Newe Ya'ar Research Center, Ramat Yishay 30095, Israel; and fifth author: Department of Natural Resources, ARO, The Volcani Center, Bet Dagan 50250, Israel.

Accepted for publication 24 March 2000.

\begin{abstract}
Oka, Y., Nacar, S., Putievsky, E., Ravid, U., Yaniv, Z., and Spiegel, Y. 2000. Nematicidal activity of essential oils and their components against the root-knot nematode. Phytopathology 90:710-715.

Nematicidal activity of essential oils extracted from 27 spices and aromatic plants were evaluated in vitro and in pot experiments. Twelve of the twenty-seven essential oils immobilized more than $80 \%$ of juveniles of the root-knot nematode Meloidogyne javanica at a concentration of $1,000 \mu \mathrm{l} /$ liter. At this concentration, most of these oils also inhibited nematode hatching. Essential oils of Carum carvi, Foeniculum vulgare, Mentha rotundifolia, and Mentha spicata showed the highest nematicidal activity among the in vitro tested oils. These oils

and those from Origanum vulgare, O. syriacum, and Coridothymus capitatus mixed in sandy soil at concentrations of 100 and $200 \mathrm{mg} / \mathrm{kg}$ reduced the root galling of cucumber seedlings in pot experiments. The main components of these essential oils were tested for their nematicidal activity. Carvacrol, $t$-anethole, thymol, and (+)-carvone immobilized the juveniles and inhibited hatching at $>125 \mu 1 /$ liter in vitro. Most of these components mixed in sandy soil at concentrations of 75 and $150 \mathrm{mg} / \mathrm{kg}$ reduced root galling of cucumber seedlings. In 3-liter pot experiments, nematicidal activity of the essential oils and their components was confirmed at 200 and $150 \mathrm{mg} / \mathrm{kg}$, respectively. The results suggest that the essential oils and their main components may serve as nematicides.
\end{abstract}

Today, plant-parasitic nematodes are controlled by cultural practices, chemical nematicides, and the growing of resistant cultivars. However, nematicide use is slated for reduction due to environmental problems and human and animal health concerns. For example, effective nematicides such as DBCP (dibromochloropropane) and EDB (ethylene dibromide) have been withdrawn from the market due to their deleterious effects on humans and the environment. Methyl bromide, the most effective and widely used fumigant for soilborne diseases and pests, including nematodes, has already been banned in some countries, and its complete withdrawal from the market is planned for most countries by international agreement. The use of nonfumigant nematicides, based on organophosphates and carbamates, is expected to increase following the withdrawal of methyl bromide, which will bring about new environmental concerns. In fact, the highly toxic aldicarb used to control insects and nematodes has been detected in groundwater (26). Therefore, alternative nematode control methods or less toxic nematicides need to be developed (12). One way of searching for such nematicidal compounds is to screen naturally occurring compounds in plants. Several such compounds, e.g., alkaloids, phenols, sesquiterpenes, diterpenes, polyacetylenes, and thienyl derivatives, have nematicidal activity (4). For example, $\alpha$-terthienyl from Tagetes spp. is a highly effective nematicidal compound (22). Other compounds with nematicidal activity have been isolated from plants, mainly from the family Asteraceae (4). However, compounds of plant origin and

Corresponding author: Y. Oka; E-mail address: okayuji@netvision.net.il

Publication no. P-2000-0509-01R

(C) 2000 The American Phytopathological Society their analogs have not been developed into commercial nematicides.

Volatile compounds from plants, especially essential oils, have antimicrobial and insecticidal activity $(7,11,18,20,25)$. Only a few essential oils and their components have been evaluated for their nematicidal effects $(10,16,17,24)$. In our present study, essential oils from 27 species and chemotypes of spices and aromatic plants were evaluated for their nematicidal effects on the root-knot nematode Meloidogyne javanica. The main components of the essential oils that revealed nematicidal activity were also tested.

\section{MATERIALS AND METHODS}

Plants, oil extraction, and analysis. The plants and plant parts used for extraction of essential oils are shown in Table 1. Essential oils were extracted from fresh plants by steam distillation for $1 \mathrm{~h}$ in a 130-liter direct steam pilot plant apparatus. Isolated oils were dried over anhydrous sodium sulfate and stored at 4 to $6^{\circ} \mathrm{C}$. The chemical composition of the essential oils with nematicidal activity was determined with a G 1800 B GCD system with an electron ionization detector (Hewlett-Packard Co., Palo Alto, CA) for high-resolution gas chromatography-mass spectrometry (GC-MS) analysis (14). Essential oils were diluted in hexane (1:100) and injected into the HP-5 fused silica capillary column $(3.0 \mathrm{~m} \times 0.25$ $\mathrm{mm}$ inside diameter), at $1.0 \mathrm{ml} / \mathrm{min}$ helium (flow rate split ratio 100:1). Temperature was programmed to $4^{\circ} \mathrm{C} / \mathrm{min}$, from 70 to $200^{\circ} \mathrm{C}$. MS were taken at $70 \mathrm{eV}$. The scanning range was 40 to $450 \mathrm{~m} / \mathrm{z}$. Essential oil components were identified by MS library match and by comparing retention times to those of authentic samples. The main components of the tested essential oils are shown in Table 2. Essential oil components $t$-anethole, carvacrol, and thymol were obtained from Sigma Chemical Co. (St. Louis), 
(+)- and (-)-carvone and (+)-limonene were obtained from Fluka Chemika-Biochemika (Buchs, Switzerland), and piperitone was obtained from Carl Roth (Karlsruhe, Germany).

Nematode. Eggs of Meloidogyne javanica were extracted from tomato (Lycopersicon esculentum cv. 144) roots infected with the nematode using sodium hypochlorite solution (6). Second-stage juveniles (J2) were collected daily from eggs and stored at $15^{\circ} \mathrm{C}$. The juveniles used in the experiments were less than 5 days old.

In vitro tests. Essential oil solutions (10\% ethanol, vol/vol) were diluted with water containing $0.3 \%$ (Tween 20 , vol/vol) to prepare given concentrations. The final concentration of ethanol was less than $1 \%$. Approximately 150 to $250 \mathrm{~J} 2$ in $20 \mu \mathrm{l}$ of water were introduced into $500 \mu \mathrm{l}$ of essential oil solution $(1,000 \mu \mathrm{l} / \mathrm{liter})$ in wells of 24-well plates (Corning Glass Inc., Corning, NY) and incubated at $25^{\circ} \mathrm{C}$. Percentages of immobile $\mathrm{J} 2$ were recorded after 2 days. Essential oils that immobilized more than $80 \%$ of the tested $\mathbf{J} 2$ population were selected. This test was repeated with selected essential oils at a concentration of $800 \mu \mathrm{l} /$ liter.

Approximately 80 to 120 nematode eggs in $10 \mu$ of water were exposed to essential oil solutions $(1,000 \mu \mathrm{l} /$ liter $)$ and incubated at $25^{\circ} \mathrm{C}$, and hatching percentage was recorded after 7 days. The hatching test was repeated with the aforementioned selected essential oils at a concentration of $600 \mu \mathrm{l} /$ liter. Tests had four replicates and were conducted at least twice.

Solutions $(125,250$, and $500 \mu \mathrm{l} /$ liter $)$ of the essential oil components $t$-anethole, carvacrol, (+)-carvone, (+)-limonene, piperitone, and thymol were prepared according to the above method. J2 (150 to 250 ) and nematode eggs (80 to 120 ) were introduced into these solutions and incubated at $25^{\circ} \mathrm{C}$. Concentrations of ethanol and Tween 20 in controls were equivalent to those in treatments with essential oils or their components. Percentages of J2 immobility and hatching were recorded after 2 and 8 days, respectively. Tests had four replicates and were repeated twice.

Pot experiments. Essential oils of Coridothymus capitatus, Carum carvi, Cymbopogon citratus, Foeniculum vulgare, Mentha rotundifolia, Mentha spicata, C- and T-type Origanum vulgare,

TABLE 1. Plants used for essential-oil extraction

\begin{tabular}{|c|c|c|}
\hline Botanical name ${ }^{\mathrm{z}}$ & Common name & Extraction part \\
\hline Achillea fragrantissima & Achiella & Foliage \\
\hline Artemisia arboresses & & Foliage \\
\hline Artemisia dracunculus & Tarragon & Foliage \\
\hline Artemisia judaica & & Foliage \\
\hline Carum carvi & Caraway & Umbels \\
\hline Coridothymus capitatus & Wild thyme & Foliage \\
\hline Cymbopogon citratus & Lemongrass & Foliage \\
\hline Foeniculum vulgare & Fennel & Umbels \\
\hline Laurus nobilis & Laurel bay & Foliage \\
\hline Lavandula officialis & Lavender & Foliage \\
\hline Mentha piperita & Peppermint & Foliage \\
\hline Mentha rotundifolia & Applemint & Foliage \\
\hline Mentha spicata & Spearmint & Foliage \\
\hline Micromeria fruticosa & & Foliage \\
\hline Myrtus communis & Myrtle & Foliage \\
\hline Ocimum basilicum & Basil & Foliage \\
\hline Origanum dayi & & Foliage \\
\hline Origanum syriacum (C-type) & Syrian oregano & Foliage \\
\hline Origanum syriacum (CT-type) & Syrian oregano & Foliage \\
\hline Origanum vulgare (C-type) & Oregano & Foliage \\
\hline Origanum vulgare (T-type) & Oregano & Foliage \\
\hline Pelargonium graveolens & Rose geranium & Foliage \\
\hline Rosmarinus officinalis & Rosemary & Foliage \\
\hline Salvia dominica & & Foliage \\
\hline Salvia officinalis & Sage & Inflorescence \\
\hline Salvia triloba & Greek sage & Foliage \\
\hline Thymus vulgaris & Thyme & Foliage \\
\hline
\end{tabular}

${ }^{\mathrm{z}} \mathrm{C}$-type $=$ carvacrol type: a plant chemotype in which carvacrol is the major component of its essential oil. CT-type = carvacrol-thymol type: a plant chemotype in which carvacrol is present in the essential oil in addition to thymol. T-type $=$ thymol type: a plant chemotype in which thymol is the major component of its essential oil (described in Table 2). and C- and CT-type Origanum syriacum diluted in ethanol (1:4) were mixed with $250 \mathrm{~g}$ of nematode-infested sandy soil $(\approx 1.5 \mathrm{~J} 2$ per $\mathrm{g}$ of soil) in 180-ml plastic pots at concentrations of 100 and $200 \mathrm{mg} / \mathrm{kg}$. Ethanol (300 and $600 \mathrm{mg} / \mathrm{kg}$ ) was mixed with the soil as a control. Soil moisture was maintained at $\approx 5 \%(\mathrm{wt} / \mathrm{wt})$. Each pot was sealed in a plastic bag and incubated at $25^{\circ} \mathrm{C}$ for 5 days. Plastic bags were removed after incubation and 1 germinated cucumber (cv. Dlila) seed, with 1-cm roots, was transplanted in each pot. Plants were placed in a growth chamber at $25^{\circ} \mathrm{C}$ for $14-\mathrm{h}$ days. The seedlings were uprooted 10 days later, and root galling indices were recorded based on a 0 to 5 rating system: $0=$ no infection, $1=1$ to $20 \%, 2=21$ to $40 \%, 3=41$ to $60 \%, 4=61$ to $80 \%$, and $5=81$ to $100 \%$ of roots galled (3). This experiment had six replicates and was repeated twice.

A similar experiment with five essential oils (Coridothymus capitatus, $M$. rotundifolia, C- and T-type $O$. vulgare, and C-type $O$. syriacum) at a concentration of $200 \mathrm{mg} / \mathrm{kg}$ was performed with 3 -liter pots filled with $4.0 \mathrm{~kg}$ of nematode-infested sandy soil $(\approx 1$ juvenile per $g$ of soil). Essential oils, diluted in ethanol (1:4), were added to the soil and mixed well. Ethanol $(600 \mathrm{mg} / \mathrm{kg})$ was mixed with the soil as a control. The pots were sealed in plastic bags and incubated for 7 days at $25^{\circ} \mathrm{C}$. Plastic bags were removed after incubation, and tomato seedlings (cv. 144) with four leaves were planted 3 days later. Seedlings were placed in a growth chamber at $25^{\circ} \mathrm{C}$ for 14 -h day and fertilized weekly with $0.1 \%$ 20-20-20 (N-P$\mathrm{K}$; Haifa Chemicals, Haifa, Israel) solution. Fresh shoot weights and root galling indices were recorded 50 days after planting. This experiment had six replicates and was conducted once.

Essential oil components $t$-anethole, carvacrol, (+)- and (-)-carvone, (+)-limonene, piperitone, and thymol were diluted in ethanol (1:4) and mixed with nematode-infested sandy soil (250 g in $180-\mathrm{ml}$ pots and $1.5 \mathrm{~J} 2$ per $\mathrm{g}$ of soil) at concentrations of 75 and $150 \mathrm{mg} / \mathrm{kg}$. Ethanol (225 and $450 \mathrm{mg} / \mathrm{kg}$ ) was mixed with the soil as a control. Each pot was sealed in a plastic bag and incubated at $25^{\circ} \mathrm{C}$ for 5 days. Germinated cucumber seeds were transplanted after incubation, and galling indices were recorded 10 days later. This experiment had six replicates and was repeated twice.

A similar experiment was performed with 3 -liter pots filled with $4.0 \mathrm{~kg}$ of nematode-infested sandy soil $(0.8 \mathrm{~J} 2$ per $\mathrm{g}$ of soil $)$ and $150 \mathrm{mg} / \mathrm{kg}$ of essential oil components. Ethanol (600 mg/kg) was mixed with the soil as a control. The experimental procedure was the same as for the 3-liter pot experiment with essential oils, except that fresh shoot weights and root galling indices were recorded 40 days after planting. This experiment had six replicates and was conducted once. Soil weights were based on dry weight in all experiments.

TABLE 2. Main components of essential oils with nematicidal activity

\begin{tabular}{|c|c|}
\hline Botanical name ${ }^{\mathrm{z}}$ & Main component \\
\hline Artemisia judaica & Artemisia ketone $(34 \%)$ \\
\hline Carum carvi & $(+)$-Carvone $(50 \%)$, limonene $(48 \%)$ \\
\hline Coridothymus capitatus & Carvacrol $(70 \%)$ \\
\hline Cymbopogon citratus & Geranial (47\%), neral $(31 \%)$ \\
\hline Foeniculum vulgare & $t$-Anethole $(43 \%)$, limonene $(6 \%)$ \\
\hline Mentha rotundifolia & $\begin{array}{l}\text { Isomers of } 1,2 \text {-epoxymenthyl acetate } \\
\quad(74 \%) \text {, piperitone }(13 \%)\end{array}$ \\
\hline Mentha spicata & $(-)$-Carvone $(58 \%)$, limonene $(19 \%)$ \\
\hline Micromeria fruticosa & Pulegone $(75 \%)$ \\
\hline Origanum syriacum (C-type) & Carvacrol $(76 \%)$ \\
\hline Origanum syriacum (CT-type) & Carvacrol $(68 \%)$, thymol $(2 \%)$ \\
\hline Origanum vulgare (C-type) & Carvacrol $(80 \%)$ \\
\hline Origanum vulgare (T-type) & Thymol $(60 \%)$ \\
\hline Thymus vulgaris & Thymol (40\%), carvacrol $(7 \%)$ \\
\hline
\end{tabular}

${ }^{\mathrm{z}} \mathrm{C}$-type $=$ carvacrol type: a plant chemotype in which carvacrol is the major component of its essential oil. CT-type = carvacrol-thymol type: a plant chemotype in which carvacrol is present in the essential oil in addition to thymol. T-type $=$ thymol type: a plant chemotype in which thymol is the major component of its essential oil. 
Data were subjected to analysis of variance (ANOVA), and means were separated according to LSD $(P=0.05)$. Data presented as percentages were transformed by inverse sine transformation $\left(\sin ^{-1} \mathrm{x}\right)$ before data analysis.

TABLE 3. Effect of essential oils $(1,000 \mu \mathrm{l} /$ liter) on mobility of Meloidogyne javanica $^{\mathrm{y}}$ second-stage juveniles (J2) and hatching of eggs

\begin{tabular}{|c|c|c|}
\hline Botanical name ${ }^{z}$ & $\% \mathrm{~J} 2$ immobility & $\%$ Eggs hatched \\
\hline Achillea fragrantissima & $28.7 \mathrm{e}$ & $16.2 \mathrm{e}-\mathrm{g}$ \\
\hline Artemisia arboresses & $38.9 \mathrm{e}$ & $9.2 \mathrm{ij}$ \\
\hline Artemisia dracunculus & $31.0 \mathrm{e}$ & $19.5 \mathrm{c}-\mathrm{e}$ \\
\hline Artemisia judaica & $85.0 \mathrm{~b}$ & $1.2 \mathrm{mn}$ \\
\hline Carum carvi & $100 \mathrm{a}$ & $0.5 \mathrm{mn}$ \\
\hline Coridothymus capitatus & $90.1 \mathrm{~b}$ & $14.3 \mathrm{f}-\mathrm{h}$ \\
\hline Cymbopogon citratus & $86.4 \mathrm{~b}$ & $7.5 \mathrm{I}-\mathrm{k}$ \\
\hline Foeniculum vulgare & $100 \mathrm{a}$ & $0.6 \mathrm{~m}-\mathrm{o}$ \\
\hline Laurus nobilis & $7.8 \mathrm{~g}$ & $29.4 \mathrm{ab}$ \\
\hline Lavandula officialis & $11.8 \mathrm{fg}$ & $23.1 \mathrm{~b}-\mathrm{d}$ \\
\hline Mentha piperita & $71.8 \mathrm{c}$ & $5.6 \mathrm{jk}$ \\
\hline Mentha rotundifolia & $100 \mathrm{a}$ & $0.2 \mathrm{o}$ \\
\hline Mentha spicata & $100 \mathrm{a}$ & $2.8 \mathrm{~lm}$ \\
\hline Micromeria fruticosa & $88.2 \mathrm{~b}$ & $2.2 \mathrm{~lm}$ \\
\hline Myrtus communis & $12.0 \mathrm{fg}$ & $24.9 \mathrm{~b}-\mathrm{d}$ \\
\hline Ocimum basilicum & $17.7 \mathrm{f}$ & $21.1 \mathrm{c}-\mathrm{e}$ \\
\hline Origanum dayi & $17.6 \mathrm{f}$ & 17.9 ef \\
\hline Origanum syriacum (C-type) & $92.3 \mathrm{~b}$ & $4.5 \mathrm{kl}$ \\
\hline Origanum syriacum (CT-type) & $83.6 \mathrm{~b}$ & $18.9 \mathrm{~d}-\mathrm{f}$ \\
\hline Origanum vulgare (C-type) & $98.9 \mathrm{a}$ & 0.5 no \\
\hline Origanum vulgare (T-type) & $89.5 \mathrm{~b}$ & $18.5 \mathrm{~d}-\mathrm{f}$ \\
\hline Pelargonium graveolens & $31.6 \mathrm{e}$ & $11.2 \mathrm{gh}$ \\
\hline Rosmarinus officinalis & $18.4 \mathrm{f}$ & $26.4 \mathrm{a}-\mathrm{c}$ \\
\hline Salvia dominica & $51.6 \mathrm{~d}$ & $10.1 \mathrm{hi}$ \\
\hline Salvia officinalis & $14.9 \mathrm{fg}$ & $16.2 \mathrm{e}-\mathrm{g}$ \\
\hline Salvia triloba & $18.5 \mathrm{f}$ & $18.5 \mathrm{~d}-\mathrm{f}$ \\
\hline Thymus vulgaris & $67.5 \mathrm{c}$ & $15.6 \mathrm{e}-\mathrm{g}$ \\
\hline Control & $2.0 \mathrm{~h}$ & $32.5 \mathrm{a}$ \\
\hline
\end{tabular}

y $\mathrm{J} 2$ and eggs were incubated in $500 \mu \mathrm{l}$ of essential oil solutions at $25^{\circ} \mathrm{C}$, and percentages of immobile $\mathrm{J} 2$ and hatching were recorded 2 and 7 days later, respectively. Values are means of combined results from two experiments with four replicates each. Values followed by the same letter in a column do not differ significantly according to LSD $(P=0.05)$.

${ }^{\mathrm{z}}$ Plant oil was extracted from C-type $=$ carvacrol type: a plant chemotype in which carvacrol is the major component of its essential oil. CT-type = carvacrol-thymol type: a plant chemotype in which carvacrol is present in the essential oil in addition to thymol. T-type $=$ thymol type: a plant chemotype in which thymol is the major component of its essential oil (described in Table 2).

TABLE 4. Effect of essential oils on mobility of Meloidogyne javanica ${ }^{\mathrm{y}}$ second-stage juveniles (J2) and hatching of eggs

\begin{tabular}{lcc}
\hline Botanical name $^{\mathrm{z}}$ & $\% \mathrm{~J} 2$ immobility & $\%$ Eggs hatched \\
\hline Artemisia judaica & $12.8 \mathrm{~g}$ & $25.6 \mathrm{ab}$ \\
Carum carvi & $100 \mathrm{a}$ & $2.2 \mathrm{f}$ \\
Coridothymus capitatus & $16.8 \mathrm{~g}$ & $22.0 \mathrm{ab}$ \\
Cymbopogon citratus & $69.3 \mathrm{e}$ & $17.0 \mathrm{c}$ \\
Foeniculum vulgare & $100 \mathrm{a}$ & $5.8 \mathrm{e}$ \\
Mentha rotundifolia & $100 \mathrm{a}$ & $2.2 \mathrm{f}$ \\
Mentha spicata & $98.1 \mathrm{~b}$ & $8.8 \mathrm{de}$ \\
Micromeria fruticosa & $86.0 \mathrm{c}$ & $21.4 \mathrm{~b}$ \\
Origanum syriacum (C-type) & $70.7 \mathrm{e}$ & $19.6 \mathrm{bc}$ \\
Origanum syriacum (CT-type) & $34.6 \mathrm{f}$ & $\ldots$ \\
Origanum vulgare (C-type) & $79.5 \mathrm{~d}$ & $11.8 \mathrm{~d}$ \\
Origanum vulgare (T-type) & $37.0 \mathrm{f}$ & $\ldots$ \\
Control & $0.6 \mathrm{~h}$ & $28.0 \mathrm{a}$ \\
\hline
\end{tabular}

y J2 and eggs were exposed to essential oil solutions $(500 \mu \mathrm{l})$ at concentrations of 800 and $600 \mu \mathrm{l} /$ liter, respectively. Percentages of immobile $\mathrm{J} 2$ and hatching were recorded 2 and 7 days later, respectively. Values are means of combined results from two experiments with four replicates each. Values followed by the same letter in a column do not differ significantly according to $\operatorname{LSD}(P=0.05)$.

${ }^{\mathrm{z}}$ Plant oil was extracted from C-type $=$ carvacrol type: a plant chemotype in which carvacrol is the major component of its essential oil. CT-type $=$ carvacrol-thymol type: a plant chemotype in which carvacrol is present in the essential oil in addition to thymol. T-type $=$ thymol type: a plant chemotype in which thymol is the major component of its essential oil (described in Table 2).

\section{RESULTS}

In vitro tests. The effects of the essential oils on $\mathrm{J} 2$ and eggs at a concentration of $1,000 \mu \mathrm{l} /$ liter were examined (Table 3 ). Twelve essential oils immobilized more than $80 \%$ of $\mathrm{J} 2$ after 2 days of incubation. Eight of twenty-seven essential oils at a concentration of $1,000 \mu \mathrm{l} /$ liter reduced hatching to less than $5 \%$, while hatching was $32.5 \%$ in the control after 7 days. Twelve oils were tested further at lower concentrations (Table 4). Only four essential oils (Carum carvi, F. vulgare, $M$. rotundifolia, and $M$. spicata) were highly effective at $\mathbf{J} 2$ immobilization and hatching inhibition at concentrations of 800 and $600 \mu \mathrm{l} /$ liter, respectively.

The main components (Table 2) of the essential oils that revealed nematicidal activity were selected according to the results. (+)-Carvone and $t$-anethole, at a concentration of $250 \mu \mathrm{l} /$ liter, were still effective at $\mathbf{J} 2$ immobilization (Fig. 1A). Thymol, carvacrol, and $t$-anethole at a concentration of $250 \mu \mathrm{l} /$ liter inhibited hatching, while $125 \mu \mathrm{l} /$ liter of $t$-anethole was also effective (Fig. 1B). Hatching percentages of eggs in piperitone and limonene solutions were higher than those in controls.

Pot experiments. In the small-pot $(180-\mathrm{ml})$ experiments, five essential oils (Coridothymus capitatus, $M$. rotundifolia, C- and Ttype $O$. vulgare, and C-type $O$. syriacum) at a concentration of $100 \mathrm{mg} / \mathrm{kg}$ were most effective at reducing root galling (Fig. 2). In the large-pot (3-liter) experiments, mixing each of these five essential oils into the soil reduced galling indices in tomato roots (Fig. 3). Roots of tomato plants grown in essential oil treated soil had very few or no galls, while control plants had heavily galled roots (Fig. 4). Fresh shoot weights of tomato plants grown in untreated soil were significantly less than those grown in essential
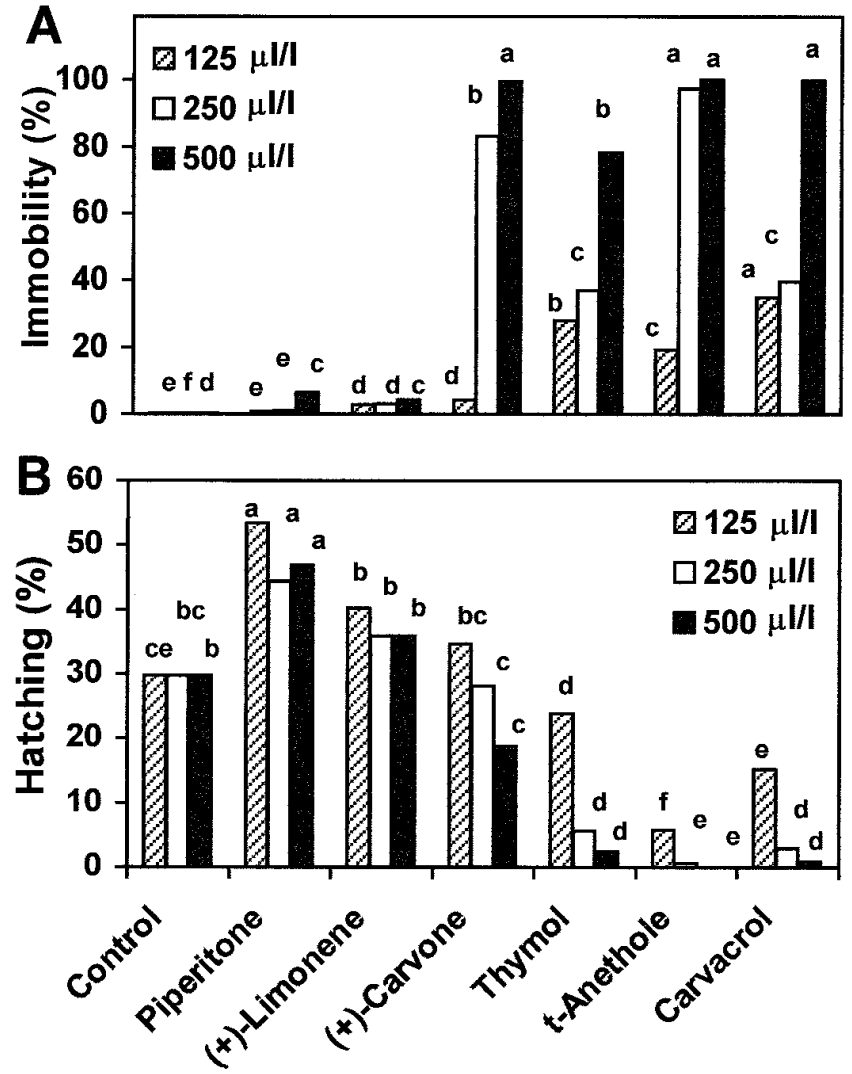

Fig. 1. Activity of essential oil components on mobility of A, second-stage juveniles and $\mathbf{B}$, hatching of eggs of Meloidogyne javanica. Immobility and hatching percentages were recorded 2 and 7 days after incubation, respectively, in solutions at concentrations of 125,250 , and $500 \mu \mathrm{l} /$ liter. Values are means of combined results from two experiments with four replicates each. Within each concentration, values with the same letter do not differ significantly according to $\operatorname{LSD}(P=0.05)$. 
oil-treated sand. The weight of tomato plants grown in untreated soil was $49.9 \pm 12.8 \mathrm{~g}$ (mean \pm standard deviation of six replicates), whereas those from soils treated with essential oils of Coridothymus capitatus, $M$. rotundifolia, C- and T-type $O$. vulgare, and C-type $O$. syriacum were $63.3 \pm 5.6,62.6 \pm 5.6,67.2 \pm 5.9$, $65.1 \pm 9.2$, and $62.8 \pm 4.5 \mathrm{~g}$, respectively.

Except for limonene, all the essential oil components at a concentration of $150 \mathrm{mg} / \mathrm{kg}$ of sand reduced galling indices in the small-pot experiment (Fig. 5A). At $75 \mathrm{mg} / \mathrm{kg}$, thymol, (+)- and (-)carvone, and carvacrol were still effective at reducing galls. In the large-pot (3-liter) experiment, all the essential oil components, except for limonene, reduced galling indices (Fig. 5B). No galls were found on tomato roots grown in pots treated with carvacrol, $t$-anethole, or (+)- and (-)-carvone. No significant differences were observed in the fresh shoot weight of these tomato seedlings (data not shown).

\section{DISCUSSION}

Plants are a source of naturally occurring pesticides. Synthetic pyrethroid insecticides have been developed based on the structures of naturally occurring pyrethrins and are used commercially for insect control (2). Several nematicidal compounds have been isolated from plants, mainly from members of the family Asteraceae (4). $\alpha$-Terthienyl and its analogs have been isolated from Tagetes spp. and found to be highly effective nematicides in vitro $(22,23)$. Other nonvolatile compounds from plants, such as polyacetylenes and benzofuran derivatives, also have nematicidal activity (5); however, none has been developed as a commercial nematicide.

Essential oils are generally used in the cosmetic, medical, and food industries, and are thought to be safe compounds for humans, animals, and the environment. However, only a few essential oils and their components have been evaluated for their nematicidal activity, e.g., the essential oils of Pelargonium graveolens, Ocimum sancutum, Ocimum basilicum, Mentha piperita, and $M$. spicata and their components (citronellol, eugenol, geraniol, and linalool) have nematicidal activity $(1,10,17,24)$. In soil, relatively higher concentrations (e.g., 1,500 ppm) of geraniol, eugenol, linalool, and peppermint oil were needed to control Meloidogyne arenarea. In the present study, the essential oils showing high nematicidal activity in vitro were from Carum carvi, F. vulgare, and $M$. rotundifolia, followed by essential oils from the family Labiatae (Micromeria fruticosa, O. syriacum, and $O$. vulgare). Among the chemotypes of $O$. vulgare and $O$. syriacum, higher nematicidal activity was found in the C-types, in which carvacrol is present at higher concentrations relative to CT- and T-types. A nematicidal activity trend existed for $\mathrm{J} 2$ and eggs in in vitro tests,

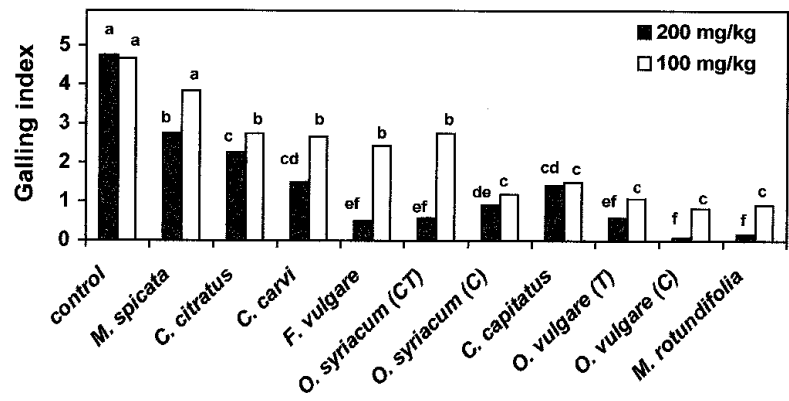

Fig. 2. Effect of soil treatment with essential oils on galls on cucumber (index of 1 to 5) caused by Meloidogyne javanica. Essential oils were mixed with nematodeinfested soil $(250 \mathrm{~g})$ at concentrations of 100 and $200 \mathrm{mg} / \mathrm{kg}$. Germinated cucumber seeds were transplanted 5 days later, and root galling indices of cucumber seedlings were evaluated 10 days later Values are means of combined results from two experiments with six replicates each. Within each concentration, values with the same letter do not differ significantly according to $\operatorname{LSD}(P=0.05)$. and most essential oils that immobilized $\mathrm{J} 2$ were also effective at inhibiting hatching. Hatching tests are useful in screening essential oils for nematicidal activity, because counting hatched juveniles is more accurate than counting immobile juveniles in a particular J2 population. Essential oils selected from the results of the in vitro tests reduced root damage caused by the nematode at lower concentrations $(100 \mathrm{mg} / \mathrm{kg})$ more than those used by others (24). These lower concentrations were probably due to the use of sandy soil and its low organic matter and clay contents and good aeration. Although some essential oils and their components have been reported to be phytotoxic at high concentrations, such as $1,500 \mathrm{mg} / \mathrm{kg}$ (24), no phytotoxic effect was observed on plants when lower concentrations were tested and plants were planted 5 or 7 days after treatment. Therefore, the nematicidal activity of these oils must be checked further using other soil types that have higher clay and organic matter contents.

The main components of the essential oils that revealed nematicidal activity were tested for nematicidal activity in vitro and in pots. The essential oils of $t$-anethole in $F$. vulgare, (+)-carvone in Carum carvi, carvacrol in C-type $O$. syriacum and $O$. vulgare, and

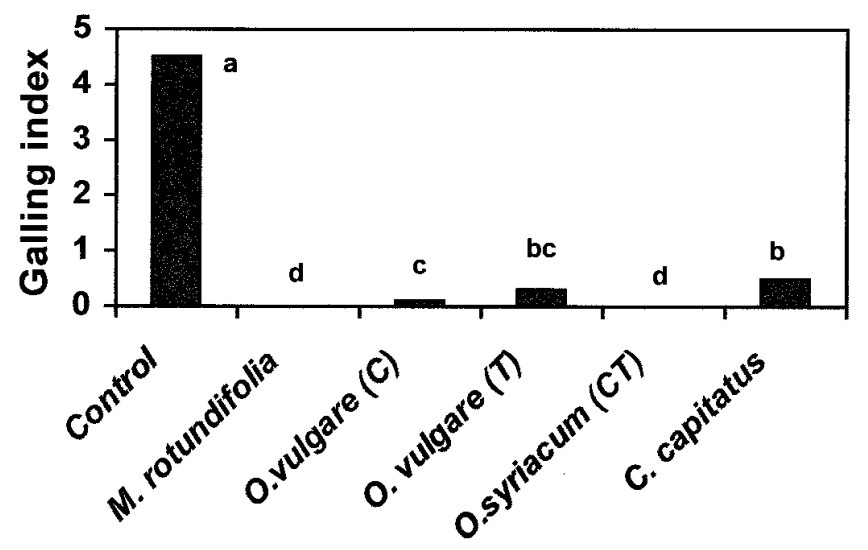

Fig. 3. Effect of soil treatment with essential oils on galls on tomato (index of 0 to 5) caused by Meloidogyne javanica. Essential oils were mixed with nematodeinfested soil $(4 \mathrm{~kg})$ at a concentration of $200 \mathrm{mg} / \mathrm{kg}$. Tomato seedlings were planted after 10 days. Root galling indices of tomato plants were evaluated 50 days later. Values are means of six replicates. Values with the same letter do not differ significantly according to $\operatorname{LSD}(P=0.05)$.

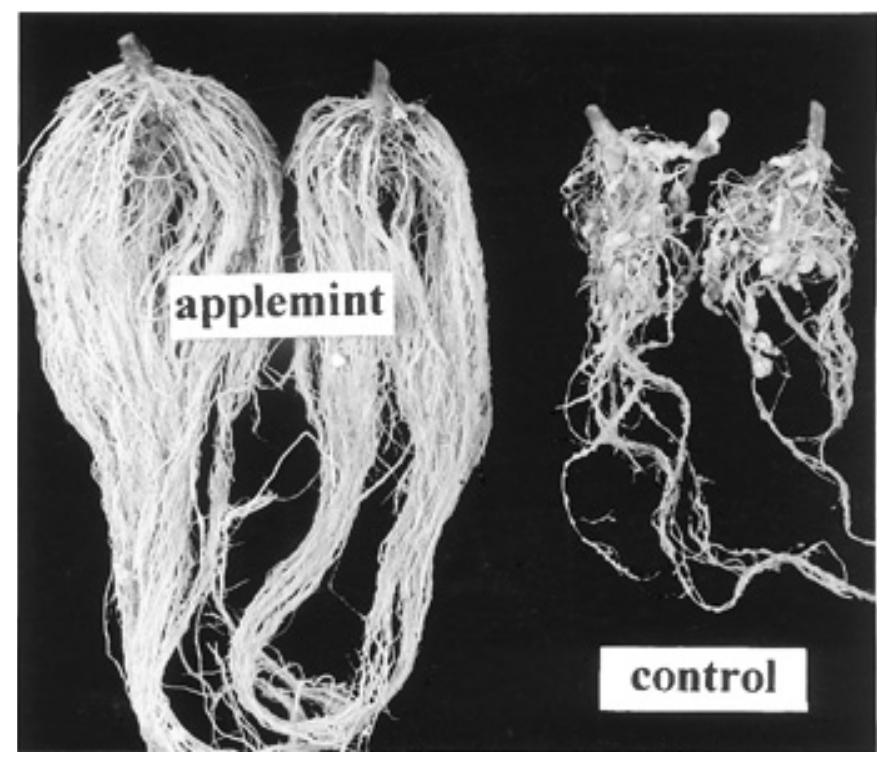

Fig. 4. Roots of tomato plants grown in nematode-infested soil treated with essential oil of Mentha rotundifolia (applemint) at a concentration of $200 \mathrm{mg} / \mathrm{kg}$ and in untreated soil (control). 
thymol in T-type $O$. syriacum and $O$. vulgare were very effective in $\mathrm{J} 2$ immobilization and hatching inhibition at concentrations as low as 250 to $500 \mu \mathrm{l} /$ liter, while piperitone and limonene in $M$. rotundifolia and other plants were less effective. The results of the 3-liter pot experiments with selected essential oils were very encouraging. Application of the oils at $200 \mathrm{mg} / \mathrm{kg}$ resulted in almost total control. Essential oils containing carvacrol were more effective than those containing thymol. This was also true of the in vitro tests. Extensive work with thymol as a nematicide was done by Soler-Serratosa et al. (21). They found the lethal concentration $\left(\mathrm{LC}_{90}\right)$ of thymol against nematode populations of Meloidogyne arenarea in soil to be $161 \mathrm{ppm}$ and that the efficiency of thymol was enhanced synergistically in combination with benzaldehyde, a synthetic essential oil of almond. The essential oil of $M$. rotundifolia showed excellent nematicidal activity in vitro and in pot experiments. Because limonene and piperitone lacked nematicidal activity at relevant concentrations in vitro and in the soil, the main components of $M$. rotundifolia essential oil, isomers of 1,2epoxy menthylacetate, are suggested to have high nematicidal activity.

The mode of action of essential oils against nematodes is unclear. In insects, several essential oils inhibit acetylcholinesterase activity (15). Moreover, essential oil compounds are antagonists of octopamine receptors of American cockroaches; octopamine is a neurotransmitter in insects. It is interesting to note that the main components of the essential oils that revealed nematicidal activity in this study have also been reported to have insecticidal activity (7). The involvement of essential oil components in interrupting the nematode nervous system is unclear; however, essential oils
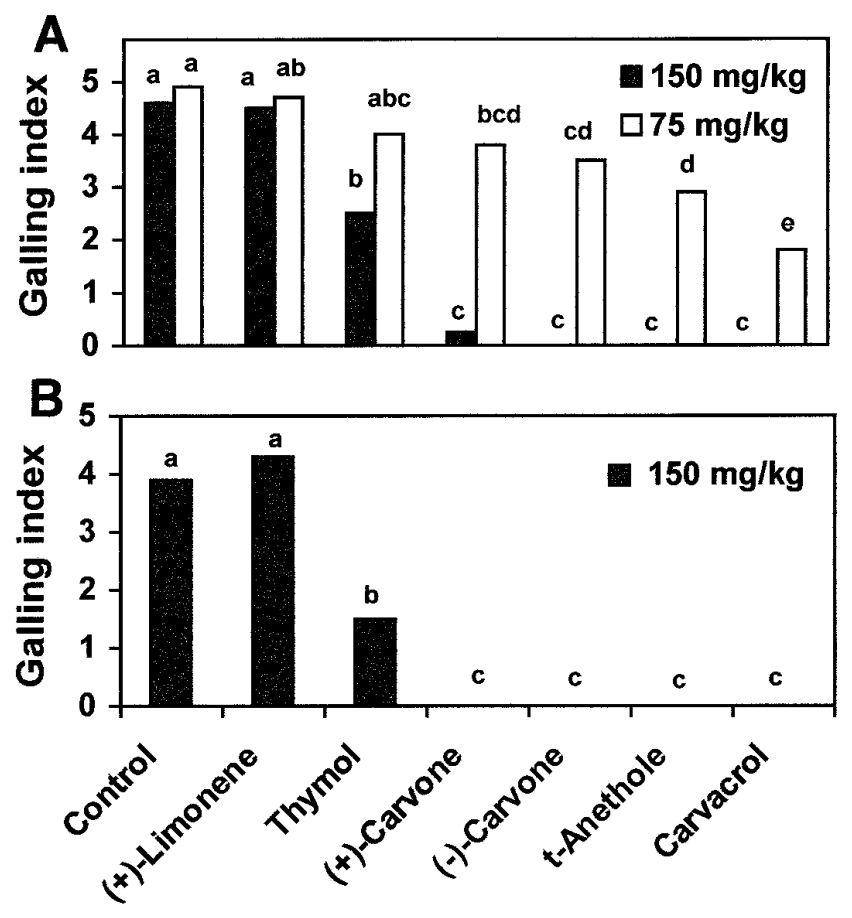

Fig. 5. Effect of soil treatment with essential oil components on Meloidogyne javanica. A, Components were mixed with nematode-infested soil (250 g) at concentrations of 75 and $150 \mathrm{mg} / \mathrm{kg}$. Germinated cucumber seeds were transplanted after 5 days. Root galling indices of cucumber seedlings were evaluated 10 days later. Values are means of combined results from two experiments with six replicates each. B, Essential oils were mixed with nematode-infested soil (4 kg) at a concentration of $150 \mathrm{mg} / \mathrm{kg}$. Tomato seedlings were transplanted after 10 days. Root galling indices of tomato plants were evaluated 40 days later. Values are means of six replicates. Within each concentration, values with the same letter do not differ significantly according to $\operatorname{LSD}(P=0.05)$. may disrupt the cell membrane of the nematode and change its permeability.

Our results suggest that essential oils have the potential for use in nematode control. Because essential oils and main components of some essential oils, such as carvacrol, thymol, $t$-anethole, and carvone, have also been reported to have fungicidal and antibacterial activities $(8,9,13,19)$, soil treatment with essential oils or their components could serve as a soil disinfectant. However, further experiments are needed to evaluate economic aspects and nematicidal activity under field conditions with other nematode species and in other types of soil.

\section{LITERATURE CITED}

1. Chatterjee, A., Sukul, N. C., Laskar, S., and Ghoshmajumdar, S. 1982. Nematicidal principles from two species of Lamiaceae. J. Nematol. 14:118-120.

2. Elliott, M. 1996. Synthetic insecticides related to the natural pyrethrins. Pages 254-300 in: Crop Protection Agents from Nature. L. G. Copping, ed. The Royal Society of Chemistry, Cambridge.

3. Garabedian, S., and Van Gundy, S. D. 1984. Use of avermectins for the control of Meloidogyne incognita on tomato. J. Nematol. 15:503-510.

4. Gommers, F. J. 1981. Biochemical interactions between nematodes and plants and the irrelevance to control: A review. Helminthol. Abstr. 50:9-24.

5. Gommers, F. J., and Bakker, J. 1988. Physiological diseases induced by plant response or products. Pages 3-22 in: Diseases of Nematodes. Vol. 1. G. O. Poinar and H.-B. Jansson, eds. CRC Press, Boca Raton, FL.

6. Hussey, R. S., and Barker, R. K. 1973. A comparison of methods of collecting inocula of Meloidogyne spp., including a new technique. Plant Dis. Rep. 57:1025-1028.

7. Isman, M. 1999. Pesticides based on plant essential oils. Pestic. Outlook 10:68-72.

8. Janssen, A. M., Sheffer, J. J. C., and Baerheim Svendsen, A. 1987. Antimicrobial activity of essential oils: A 1976-1986 literature review: Aspects of the test methods. Planta. Med. 53:395-398.

9. Kurita, N., Miyaji, M., Kurane, R., and Takahara, Y. 1981. Antifungal activity of components of essential oils. Agric. Biol. Chem. 45:945952.

10. Leela, N. K., Khan, R. M., Reddy, P. P., and Nidiry, E. S. J. 1992. Nematicidal activity of essential oil of Pelargonium graveolens against the root-knot nematode Meloidogyne incognita. Nematol. Medit. 20:5758 .

11. Müller-Riebau, F., Berger, B., and Yegen, O. 1995. Chemical composition and fungitoxic properties to phytopathogenic fungi of essential oils of selected aromatic plants growing wild in Turkey. J. Agric. Food Chem. 43:2262-2266.

12. Noling, J. W., and Becker, J. O. 1994. The challenge of research and extension to define and implement alternatives to methyl bromide. J. Nematol. 26:573-586.

13. Paster, N., Juven, B. J., Shaaya, E., Menasherov, M., Nitzan, R., Weisslowicz, H., and Ravid, U. 1990. Inhibitory effect of oregano and thyme essential oils on moulds and foodborne bacteria. Lett. Appl. Microbiol. 11:33-37.

14. Ravid, U., and Putievsky, E. 1985. Composition of essential oils of Thymbra spicata and Satureja thymbra chemotypes. Planta. Med. 51:337-338.

15. Ryan, M. F., and Byrne, O. 1988. Plant-insect coevolution and inhibition of acetylcholinesterase. J. Chem. Ecol. 14:1965-1975.

16. Sangwan, N. K., Verma, B. S., Verma, K. K., and Dhindsa, K. S. 1990 Nematicidal activity of some essential plant oils. Pestic. Sci. 28:331-335.

17. Sangwan, N. K., Verma, K. K., Verma, B. S., Malik, M. S., and Dhindsa, K. S. 1985. Nematicidal activity of essential oils of Cymbopogon grasses. Nematologica 31:93-99.

18. Shaaya, E., Ravid, U., Paster, N., Juven, B., Zisman, U., and Pisarev, V. 1991. Fumigant toxicity of essential oils against four major storedproduct insects. J. Chem. Ecol. 17:499-504.

19. Shukla, H. S., and Tripathi, S. C. 1987. The antifungal substances in oil of anise (Pimpinella anisum L.). Agric. Biol. Chem. 51:1991-1993.

20. Singh, A. K., Dikshit, A., Sharma, M. L., and Dixit, S. N. 1980. Fungitoxic activity of some essential oils. Econ. Bot. 34:186-190.

21. Soler-Serratosa, A., Kokalis-Burelle, N., Rodríguez-Kábana, R., Weaver, C. F., and King, P. S. 1995. Allelochemicals for control of plant-parasitic nematodes. 1. In vivo nematicidal efficacy of thymol and thymol/benzaldehyde combinations. Nematropica 26:57-71.

22. Uhlenbroek, J. H., and Bijloo, J. D. 1958. Investigations on nemati- 
cides. I. Isolation and structure of a nematicidal principle occurring in Tagetes roots. Recl. Trav. Chim. Pays Bas 77:1004-1008.

23. Uhlenbroek, J. H., and Bijloo, J. D. 1960. Investigations on nematicides. III. Polythienyls and related compounds. Recl. Trav. Chim. Pays Bas 79:1181-1196.

24. Walker, J. T., and Melin, J. B. 1996. Mentha $\times$ piperita, Mentha spicata and effects of their essential oils on Meloidogyne in soil. J. Nematol.
28:629-635.

25. Wilson, C. L., Solar, J. M., El Ghaouth, A., and Wisniewski, M. E. 1997. Rapid evaluation of plant extract and essential oils for antifungal activity against Botrytis cinerea. Plant Dis. 81:204-210.

26. Xaki, M. H., Moran, D., and Harris, D. 1982. Pesticides in groundwater: The aldicarb story in Suffolk Country. N.Y. Am. J. Public Health 72:1391-1395. 